\title{
Recomendaciones para elaborar y revisar artículos científicos
}

\section{Recommendations for preparation and review of scientific articles}

\section{Francisco Rojas Ochoa}

Profesor. Escuela Nacional de Salud Pública. La Habana, Cuba.

\begin{abstract}
Estas recomendaciones fueron escritas a principios del año 2001. Se han utilizado en los numerosos cursos de redacción científica en que he participado, también por otros docentes.
\end{abstract}

Sin embargo seguimos recibiendo textos en que se encuentran errores que pudieron evitarse si se aplicaran estas proposiciones. Estos errores los he conocido incluso de algunos que asistieron a los cursos.

Parecería que por lo elemental de las recomendaciones se les ignora.

No obstante insisto hoy, 10 años después, en proponer que se tengan en cuenta, ya que son numerosos los autores que dicen les han sido útiles.

Sigue el texto redactado en el 2001.

Se enumeran en apretada síntesis, algunas recomendaciones para elaborar y revisar informes, unas recogidas de varias fuentes, y otras nacidas de la experiencia propia. La intención principal no es promover que se adopten al pie de la letra y sistemáticamente, sino motivar la reflexión sobre cada recomendación propuesta.

Esto puede ser útil a los autores, trátese, de artículos científicos, informes administrativos, textos de discursos u otra expresión comunicativa. 


\section{Revista Cubana de Salud Pública. 2011;37(3):359-361}

1. Escriba en español. Con esto quiero decir que no utilice palabras de otro idioma en su texto. Si el término no existe en español (hay unos pocos ejemplos), escríbalas en letra cursiva o entre comillas. Tenga cuidado con el uso de gerundios.

2. Tenga un buen diccionario a su alcance cuando trabaje. Consúltelo ante toda duda. Recibirá de esta práctica gran enseñanza. Mi preferido es el de la Real Academia Española. También es excelente El Pequeño Laurose Ilustrado.

3. No utilice latinajos, están crecientemente fuera de uso. Pero son tolerables si se manejan con prudencia en su frecuencia y atendiendo con precisión a su significado.

4. No abuse de las referencias o citas. Lo importante no es el número, sino su pertinencia. También que sean recientes, de temas científicos actuales. Recomiendo utilizar el método de referencia del "grupo de Vancouver" en artículos y el Harvard en libros.

5. Las citas textuales se tomarán siempre del original. Las citas de citas son riesgosas. Si las utiliza dígalo en su texto o en las referencias.

6. No subraye. Este recurso para enfatizar una palabra o frase se está abandonando. Se sustituye en las computadoras con las "negritas" cuando se considere absolutamente necesario.

7. No utilice ni admita en el documento palabras o frases que causen duda a Ud. mismo o no entienda. Otros dudarán más y entenderán menos.

8. Separe o distinga bien en el texto sus opiniones o información que son propias de las de otro origen (autores, instituciones...).

9. Toda revisión se hará sobre el documento, y no en pantalla de computadora. Un vez revisado y corregido, someta el documento al control ortográfico de la computadora.

10. Imprímalo entonces y revíselo de nuevo en forma crítica. Una revisión adicional debería ser encomendada a otra persona o a varias.

11. Si se consigue incluir en esa nómina a revisores que verosílmente van a disentir no dude en hacerlo.

12. Siempre revise de la primera a la última palabra.

13. Siempre que haga una corrección revise toda la página en que la hizo.

14. Siempre verifique contra fuentes u originales, al menos dos veces, las cifras, fechas, edades, nombres propios, siglas, fórmulas y tablas estadísticas.

15. Verifique que los nombres que aparecen más de una vez están siempre escritos de igual modo.

16. Sea muy cuidadoso con el uso de altas (mayúscula) y bajas (minúsculas) y los signos ortográficos. Se aprecia entre autores cubanos un exagerado uso de mayúsculas, también un uso caótico de las comas.

17. Verifique que no olvide la fecha del documento. Siempre debe constar en algún lugar del texto. También cerciórese de que lleva firma si se requiere. "Firma", no

http://scielo.sld.cu 
equivale a escribir el nombre del autor o autores, que aparecerán o no según norma o necesidad. La firma ha de ser hológrafa o autógrafa (de propia mano).

18. Compruebe en los cambios de página, la continuidad de las ideas y la división de párrafos al cambiar de página.

19. Verifique que cada página está numerada (a veces se exceptúa la primera), y que están en orden correcto.

20. Mantenga su mesa de trabajo libre de recipientes con líquidos. Un buena taza de café puede deteriorar irreversiblemente un manuscrito $u$ original del que no hay duplicado, ni buen registro en la memoria.

Recibido: 11 de abril de 2011.

Aprobado: 13 de mayo de 2011.

Francisco Rojas Ochoa. Escuela Nacional de SaLud Pública. Calle 100 No.10132 e/Perla y E. Altahabana, Boyeros.

La Habana, Cuba. Correo electrónico: concuba@infomed.sld.cu 